УДК 929:27(470.34)”18”(045)

\title{
М.Ю. Половникова
}

\section{СТЕФАН КАШМЕНСКИЙ И ЕГО РЕЛИГИОЗНО-ПРОСВЕТИТЕЛЬСКАЯ И МИССИОНЕРСКАЯ ДЕЯТЕЛЬНОСТЬ В ВЯТСКОЙ ГУБЕРНИИ ВО ВТОРОЙ ПОЛОВИНЕ ХІХ ВЕКА ${ }^{1}$}

В статье на основе архивных материалов и опубликованных источников рассматривается жизнь и деятельность одного из видных миссионеров и просветителей Российской империи второй половины ХІХ столетия - Стефана Кашменского. В силу изменившейся религиозной политики в Российской империи во второй половине XIX в. происходят изменения в религиозно-просветительской и миссионерской работе в Вятской губернии. Особый вклад в развитие миссионерской деятельности в Вятской епархии внёс епархиальный миссионер, кафедральный протоиерей Стефан Кашменский. В статье отражается вклад Стефана Кашменского в организацию полноценной работы с иноверцами и старообрядцами. Для усиления работы с иноверцами по его инициативе в Вятской губернии был открыт Вятский комитет Православного миссионерского общества. Стефан Кашменский способствовал переустройству миссионерской работы со старообрядцами в Вятской епархии. Для этого при поддержке духовенства он открыл противораскольническую школу в г. Вятке для подготовки миссионеров из среды крестьян. По постановлению Святейшего Синода опыт организации противораскольнических школ должен был распространяться на всей территории Российской империи. Но главный результат работы Стефана Кашменского - это создание Вятского братства Святителя и Чудотворца Николая, которое вело работу по трём основным направлениям: со старообрядцами, с нерусским населением и, позднее, с сектантами. Так, Стефан Кашменский своей деятельностью сумел улучшить положение Русской православной церкви в Вятской губернии и подготовить миссионеров для ведения работы по всем религиозным направлениям в Вятской епархии.

Ключевые слова: Русская православная церковь, Вятская губерния, Вятская епархия, Стефан Кашменский, миссионерская деятельность, старообрядчество.

DOI: 10.35634/2412-9534-2019-29-4-593-602

Вторая половина XIX столетия для Российской империи оказалась временем перемен. Начатая Александром II либерализация общественной жизни повлекла за собой изменения и в религиозной сфере. Рост инакомыслия стал причиной ухода от Русской православной церкви значительной части приверженцев православия. В такой ситуации произошло изменение религиозной политики государства в русле усиления религиозно-просветительской и миссионерской деятельности среди уклоняющегося от РПЦ населения, в первую очередь среди старообрядческого, иноверческого и - особенно на рубеже веков - сектантского.

Проводниками подобной масштабной работы государства стали выдающиеся деятели своего времени. Одним из таких подвижников был известный в Российской империи епархиальный миссионер, кафедральный протоиерей Стефан Кашменский.

Стефан Никифорович Кашменский родился в 1817 г. в с. Рудовка Шацкого уезда Тамбовской губернии в семье священника. Впоследствии, ещё до школы, отца Стефана перевели в с. Шереметево по просьбе его владелицы, Парасковьи Николаевны Ланской. В имении Ланской, пользуясь покровительством этой щедрой помещицы, многодетная семья (помимо Стефана в семье было ещё два сына и три дочки) жила, не зная нужды. Отец Никифор часто брал сына в дом помещицы для исправления церковных треб [15, с. 440].

Во время учёбы в духовном училище, «как это нередко практикуется по духовно-учебному ведомству» $[15$, с. 441$]$, дети получили разные фамилии. Так, Стефан Никифорович получил фамилию «Кашменский» по названию р. Ка́шмы, которая протекает на его родной земле. Одному из братьев дали фамилию Любомудров, другому - Предтеченский. Все братья были священниками, а одна из сестёр - Ольга Никифоровна - мать известного преосвященного Антония (Вадковского).

Стефан Никифорович с детства хорошо пел и во время учёбы в духовном училище, а затем - в семинарии состоял певчим архиерейского хора. Занятия пением отвлекали от учёбы, но частые репетиции («спевки»), продолжительные службы, а также поездки по епархии всё же не мешали учиться.

\footnotetext{
${ }^{1}$ Исследование выполнено при финансовой поддержке РФФИ в рамках научного проекта № 19-09-00449.
} 
И Стефан Кашменский, благодаря своему прилежанию, весьма успешно прошёл курс обучения сначала в духовном училище, а затем и в семинарии, где оказался в числе наиболее отличившихся учеников семинарии и стал казённым стипендиатом в Киевскую духовную академию (здесь он находился в звании регента академического хора). Стефан Кашменский часто вспоминал своих наставников по академии: архиепископа Иннокентия (Борисова), протоиерея Скворцова и др., а также митрополита Макария (Булгакова), с которым он одновременно проходил академический курс и после учёбы сохранил связь. Впоследствии, в 1867 г., Стефан Кашменский вновь побывал в Киеве и принял участие в праздновании юбилея родной Киевской духовной академии.

В 1841 г., сразу по окончании Киевской духовной академии со степенью магистра богословия, он был назначен в г. Вятку наставником Вятской духовной семинарии по философским наукам и немецкому языку. Практически всю свою взрослую жизнь, около полувека, Стефан Кашменский служил в Вятке. «В первые 25 лет он проходил учебную службу, сперва преподавателем в местной Духовной семинарии, а с 31 января 1853 г. законоучителем в Губернской гимназии» [2, с. 47]. 22 октября 1846 г. С. Кашменский принял сан священника и занял место священника при церкви тюремного замка. Впоследствии, помня об этой первой должности, Стефан Кашменский «всегда служил соборне в этой церкви литургию в храмовый праздник Царицы Александры и всенощную в канун праздника, при участии хора певчих любителей из чиновников Губернского Правления» $[15$, с. 442].

После перехода в Царевскую, во имя Константина и Елены, церковь Стефан Кашменский покинул семинарию и стал законоучителем при мужской и женской гимназиях. Эти обязанности он совмещал с обязанностями приходского священника и духовника городского духовенства, а также давал частные уроки в доме вятского губернатора А. И. Середы (состоявшего в этой должности в $1843-$ 1851 гг.). Несмотря на большую занятость, в это время он также занимался составлением различных поучений и слов к пастве, писал краткие брошюры о богослужении, а также приступил к воплощению давно вынашивавшейся - с самого приезда в Вятку - идеи написать обширный труд «Систематический свод учения Св. Отцов Церкви о душе Христианской» [6-8]. Впоследствии, результаты данной работы поспособствовали составлению изречений Священного Писания для подготовки учеников противостарообрядческой школы, открытой в 1875 г., к собеседованиям со старообрядцами и для защиты православия.

Стефан Никифорович стремился к тому, чтобы его ученики не только знали содержание учебника и его уроки, но и постоянно расширяли круг своих знаний чтением книг по разным наукам. «Его стараниями для класса, в котором он преподавал, было составлено особое и довольно значительное собрание книг. В то время эта ученическая библиотека была новостью, - учреждением, не имевшим образца для себя» [16, с. 102]. Изложение лекций Кашменским не отличалось живостью и красноречием, было достаточно сухим, но при этом строго выверенным, логичным, отражавшим основное содержание предмета. По свидетельствам его окружения, Кашменский никогда не отличался пустословием, его беседы всегда отличались глубиной, содержательностью и целесообразностью.

В течение нескольких десятилетий Стефан Кашменский занимался учительской деятельностью: работал в Тюремной церкви в течение 7 лет, где обратил в православие 11 раскольников; был воспитателем молодого поколения священнослужителей в Вятской духовной семинарии (по классу логики и психологии) практически 12 лет; был учителем закона Божьего «в вятских гимназиях - мужской и женской - Мариинской и в Епархиальном женском училище» $[9$, с. 96]; в губернской мужской гимназии служил почти 15 лет (1850-1865); в Мариинской женской - 6 лет; в Епархиальном женском училище - 2 года.

После 25 лет учительской работы 25 июня 1866 г. Стефан Кашменский был назначен Агафангелом (Соловьёвым), епископом Вятским и Слободским в 1860-1866 гг., кафедральным протоиереем, и в этой должности состоял 23 года. Связь между епископом Агафангелом и Стефаном Кашменским была тесной благодаря склонности обоих к аскетизму и к общим воззрениям. И в тяжёлый для семьи Кашменского период, связанный с трагической гибелью двух его сыновей (они утонули летом 1871 года в р. Вятке), преосвященный Агафангел оказал Кашменскому моральную поддержку.

В 1867 г. по собственному желанию Стефан Кашменский был уволен с должности законоучителя губернской гимназии. С этого времени он полностью посвятил себя делам Вятской епархии. В 1870 г. при непосредственном участии Стефана Кашменского был учреждён Вятский комитет Православного миссионерского общества (открыт 28 мая 1870 г.). В 1875 г. по его настоянию и под его руководством начала работу противостарообрядческая школа, в дальнейшем оказавшаяся в ведении 
Стефан Кашменский и его религиозно-просветительская и миссионерская деятельность... 595 СЕРИЯ ИСТОРИЯ И ФИЛОЛОГИЯ

Вятского братства Святителя и Чудотворца Николая и «ставшая крупнейшим в епархии учебным заведением по подготовке православных миссионеров» [10, с. 347-350].

В должности кафедрального протоиерея Стефан Кашменский занимался устройством в Кафедральном соборе пещерной церкви, куда чуть позднее были доставлены мощи некоторых святых, почитавшихся в Киеве. Также, помимо прямых обязанностей, длительный период Стефан Кашменский занимался публикацией «сказаний» о Вятской иконе Святителя Николая и обратился к миссионерской деятельности среди старообрядческого населения. Так, «на епархиальной службе он избрал для себя главным образом миссионерскую деятельность против раскола, которая доставила ему достойную известность» [2, с. 47]. Главным (епархиальным) миссионером Кашменский состоял на протяжении 20 лет, и за этот период «обратил в православие множество раскольников, язычников (50 лиц), лютеран (4 лица), магометан и даже одного из евреев, — всех обращённых им в православие 107 лиц» $[9$, с. 96].

Стефан Никифорович с этого времени постоянно разъезжал по территории Вятской епархии и проводил беседы со старообрядцами. Такие поездки продолжались по нескольку месяцев (два и больше). Во время пребывания в Вятке Стефан Кашменский теперь «каждую свободную минуту посвящает изучению раскола и составлению полемических противоречивых сочинений» [15, с. 445]. Это служение имело для Кашменского огромное значение, поэтому «он с упорной настойчивостью принялся за изучение раскола и его разветвлений, собирал старопечатные книги и древние рукописи, за которыми просиживал целые дни от раннего утра до глубокой ночи» [16, с. 102], занимаясь отбором необходимого материала для миссионерских собеседований и собственных пособий по ведению миссионерской работы. Так, для получения более ценных и информативных материалов Кашменский совершил в 1876 г. продолжительную поездку «по тем местам России, где можно было лично беседовать с знаменитыми противораскольническими деятелями, как Павел Прусский» [15, с. 445], отцом настоятелем Московского Николаевского единоверческого монастыря. Эта поездка длилась более четырёх месяцев и была посвящена изучению старообрядческих книг. Во время недельного пребывания в Почаевской лавре у Агафангела (в то время уже являвшегося архиепископом Волынским и Житомирским) Кашменский высказал мысль о создании противостарообрядческой школы в Вятке и о своих планах по дальнейшей миссионерской работе. Именно во время этой поездки он начал задумываться о создании специального братства для работы со старообрядческим населением и о возможности развития школьного дела. Кроме того, эта поездка дала достаточно материалов для составления «Руководства к собеседованию с мнимыми старообрядцами, отпавшими от Св. Церкви» [5]. Стефан Кашменский понимал, что главная проблема местного духовенства заключалась в незнании старообрядческих книг, их учения. В этом руководстве Стефан Кашменский приводил материалы из различных старообрядческих книг, которые должны были помочь миссионерам в ведении бесед и диспутов со староверами. Кроме того, «в своём труде протоиерей даёт практические советы, как следует вести беседу со старообрядцами, какой тон избрать, что отвечать на те или иные вопросы» [11, с. 145].

За свою жизнь Стефан Кашменский при выполнении миссионерских обязанностей и для исполнения собственных религиозных обетов совершил путешествия в Киев, Санкт-Петербург, Казань, Москву, а также побывал в Палестине. В 1886 г., незадолго до своей смерти, он решился на совершение паломничества в Иерусалим, где, несмотря на преклонный возраст, успел посетить все святыни и поклониться им. Кроме того, от «отца настоятеля Русской миссии в Иерусалиме, достоуважаемого архимандрита Антонина [Капустина], он снабжён был обширною коллекцией старинных Византийских монет, интересовавших покойного о. протоиерея находящимися на них изображениями Св. Креста четырехконечной формы» $[15$, с. 446$]$.

Во время возвращения домой из Палестины Стефан Кашменский был представлен великому князю Сергею Александровичу, являвшемуся в т. ч. и председателем Императорского Православного Палестинского общества, и просил его стать покровителем Вятского братства Святителя и Чудотворца Николая (коим великий князь и согласился стать). Эта просьба была связана с переживаниями Кашменского за будущую судьбу его детища - Вятского братства. В последующие годы своей жизни Стефан Кашменский с восторгом вспоминал о встрече с великим князем Сергеем Александровичем в его с. Ильинском. Также по возвращении из Святой Земли в Санкт-Петербурге Кашменский «принял, по особому приглашению, звание члена Палестинского Общества, состоял членом и некоторое время председательствующим в Вятском Благотворительном Обществе» [9, с. 97].

Несмотря на огромную занятость и широкий круг деятельности, Кашменский стал автором ряда пособий, предназначенных для его учеников и всех желающих. Для современников и соратников 
Кашменский «являл себя примером неутомимого трудолюбия, исполнительности, ревности о правде, честности и ревности о славе Божией и Св.[ятой] Церкви Христовой» $[9$, с. 98$]$.

Стефан Кашменский отличался энергичностью, трудолюбием, но во второй половине 1888 г. начались проблемы со здоровьем... К концу года состояние Стефана Никифоровича стало вызывать беспокойство у окружающих. Тем не менее он продолжал заниматься работой и, главным образом, писал заметки для своей школы. В 1889 г. состояние Кашменского ухудшилось. О его болезни (рак печени) знало вятское общество, но всё равно уход его стал тяжёлым ударом для всей Вятской губернии и Вятской епархии.

Стефан Кашменский умер 28 января 1889 г., на 72 году жизни. Живы были его три сына, состоявшие на государственной службе в Вятской губернии, а также три дочери, вышедшие замуж за лиц, работавших в сфере народного просвещения. В течение своей жизни за различные заслуги Стефан Никифорович Кашменский получил все отличия, положенные для лиц духовного ведомства, и имел знаки орденов Св. Анны 2-й степени, украшенной Императорской короною, и Владимира - 4-й и 3-й степени, а также наперстный крест из Кабинета Его Величества с украшением и знак Красного Креста $[15$, с. 448$]$

За свою долгую и плодотворную жизнь Стефан Кашменский сделал очень много для Вятской епархии и её населения. В своей миссионерской работе огромное внимание уделял он основному направлению религиозной деятельности в Вятской епархии: работе со старообрядцами. Ещё в 1830 -е гг. там была создана миссия для борьбы со старообрядческой деятельностью. Но наибольший авторитет миссия приобрела в 1870-1880-е гг., когда её возглавил протоиерей Стефан Кашменский. До него предпринимались неудачные попытки, например, епископом Палладием (Пьянковым), реорганизовать миссию посредством разделения службы священника и миссионера. Но только Кашменскому удалось добиться от епархиальных властей материальной помощи священнослужителям, занимавшимся исключительно миссионерской работой. В итоге он смог изменить структуру миссии (теперь миссионеры не должны были одновременно возглавлять приход, чтобы иметь средства к существованию), наладить механизм работы организации, что повысило эффективность её деятельности среди староверов.

Планы же Кашменского были намного шире, чем руководство миссией: он планировал создать новую организацию, цели и задачи которой были бы связаны исключительно с содействием епархиальной власти и духовенству Вятской епархии в их работе со старообрядческим населением. Необходимость в такой организации была, т. к. в 1870-1880-е гг. «многие православные не единицами, а даже целыми селениями стали уклоняться〉 в староверие [4, с. 292]. Вятский комитет Православного миссионерского общества, открытый при помощи Стефана Кашменского, не мог справиться с такими изменениями своими силами. Поэтому Кашменский решил «основать в г. Вятке такое учреждение, где бы православные крестьяне могли знакомиться со старинными книгами, уважаемыми старообрядцами, чтобы по этим книгам беседовать с ними о вере в местах своего жительства» [3, с. 4]. Протоиерей Кашменский делал ставку на подготовку православных крестьян из приходов с высокой численностью старообрядческого населения для работы со староверами.

Первым шагом к воплощению задуманного Кашменским в жизнь стало открытие в 1870 -е гг. в Вятке противостарообрядческой школы. В Елабуге, где Кашменский находился по долгу службы, он получил первоначальную финансовую поддержку для начала осуществления своих планов в жизнь. Когда 29 ноября 1871 г. Кашменский «собрался в обратный путь, то при прощании с ним один из достопочтеннейших граждан г. Елабуги Дмитрий Иванович Стахеев сам, без всякой просьбы» пожертвовал Кашменскому на создание задуманной им школы для подготовки крестьян к противораскольнической деятельности 2000 руб. [4, с. 293]. Но для работы школы нужны были значительные средства, поэтому Кашменский активно занимался изысканием средств на нужды школы и её учащихся, обращался с просьбами о пожертвованиях к частным благотворителям, епархиальному духовенству и епархиальным съездам. В результате Кашменский получил значительную поддержку. Так, Д. И. Стахеев помимо 2000 руб., пожертвованных в 1871 г., выделил ещё 4500 руб. Другие жители Елабуги также присоединились к благотворительной деятельности и выделили средства для нужд школы: И. Г. Стахеев - 300 руб., П. К. Ушков - 200 руб., И. И. Стахеев - 100 руб. Вятский уроженец Алексей Яковлевич Прозоров, проживавший в Санкт-Петербурге, пожертвовал 1000 руб. Впоследствии Кашменский нашёл поддержку у населения и духовенства Вятской губернии. Духовенство включилось в процесс сбора средств и выделило в январе 1877 г. 1123 руб. 78 коп. Епархиальные съезды поддержали такую инициативу материальной помощью [4, с. 294]. Пожертвования способст- 
Стефан Кашменский и его религиозно-просветительская и миссионерская деятельность... 597 СЕРИЯ ИСТОРИЯ И ФИЛОЛОГИЯ

вовали развитию деятельности Кашменского, который в итоге занялся приобретением дома для школы и воплощением в жизнь основной задумки: открытия противораскольнического братства.

Теперь нужно было добиться разрешения на открытие училища. Так, «главный миссионер Вятской епархии, кафедральный протоиерей Стефан Кашменский, в августе месяце 1875 года подал Его преосвященству доклад, в котором испрашивал святительское благословение положить начало противураскольническому училищу из крестьян» [12, с. 269]. Доклад был передан для обсуждения Епархиальному съезду, начавшему свою деятельность в том же месяце. На Съезде была рассмотрена и принята инициатива Кашменского, а для успешного функционирования училища на его нужды было указано «отчислить из церковных сумм... в 1876 году 1289 рублей 95 копеек, а в следующие годы, впредь до усмотрения, 3457 рублей 30 копеек» [12, с. 269-270]. 29 августа 1875 г. Епископ Вятский и Слободской Аполлос утвердил решение Съезда, и 12 ноября 1875 г. училище было открыто. Изначально школа функционировала в квартире Кашменского в кафедральном доме, и в первый год в ней обучалось 15 чел. (причём среди них была одна женщина).

Первых учеников в созданное училище Кашменский отбирал лично, во время своих разъездов как епархиального миссионера по территории Вятской епархии. В беседах с духовенством приходов с большим количеством старообрядцев он просил указать способных благочестивых крестьян, которые подходили для его целей. Со всеми рекомендованными крестьянами он лично беседовал и отбирал тех, кого желал пригласить в Вятку для обучения. В результате такой деятельности Кашменский нашёл первых учеников и помощников. Важно отметить, что на протяжении 1875 г. в Вятке к Кашменскому приходили взрослые крестьяне, которые желали обучаться ведению миссионерской работы.

Это был первый шаг к осуществлению грандиозных планов протоиерея Кашменского. Для привлечения в училище способных крестьян в декабре 1875 г. он обратился в Вятское губернское земское собрание с просьбой, чтобы крестьяне, желавшие поступить в училище, могли получить билеты на бесплатный проезд от дома до Вятки и обратно. Эта просьба была удовлетворена собранием, и на проезд потенциальным ученикам было выделено из губернских сборов 150 руб. [12, с. 270-271]. Так в 1875 г. начинается история противораскольнического училища, как основы для создания более масштабной организации в Вятской епархии.

Следующим шагом стала подготовка к созданию Вятского братства Святителя и Чудотворца Николая. Основные события создания братства и источники, в которых отражены данные моменты, рассмотрены в работах К. В. Плетенёва, Е В. Царёвой и др. [14; 19]. На создание Вятского братства Стефану Кашменскому потребовалось несколько лет, в течение которых он подготовил чёткий план создания организации, сформулировал её цели и задачи, получил разрешение Святейшего Синода и благословение Высокопреосвященства Вятской епархии епископа Аполлоса, изыскал деньги для её функционирования и на многое другое. Финансовую поддержку Кашменский получил и от населения как Вятской губернии, и от соседей.

Основой для Вятского братства стала действовавшая противостарообрядческая школа. В итоге, после продолжительной подготовки, в апреле 1882 г. кафедральный протоиерей Стефан Кашменский выступил с предложением о создании Вятского братства, разработав его структуру и будущий Устав. В номере «Вятских Епархиальных ведомостей» от 1 октября 1882 г. было опубликовано объявление о скором открытии братства Святителя и Чудотворца Николая, которое «...по проекту его устава, будет иметь своею целью содействовать сближению с православной церковью отделившихся от неё по недоразумениям, возникшим между некоторыми православными предками нашими вследствие предпринятого патриархом Никоном исправления церковно-богослужебных книг» [1, с. 515].

Также говорилось о том, что братство будет заниматься главным образом упрочением позиций открытой в 1875 г. в Вятке Стефаном Кашменским школы для подготовки грамотных православных крестьян. Епископ Вятский и Слободской Аполлос в связи с открытием братства пожертвовал новый «принадлежащий архиерейскому дому двухэтажный флигель для братской школы» [13, с. 567] на берегу р. Вятки, расположенный в северо-восточном углу архиерейского сада. Этот просторный дом был необходим будущему братству, поскольку до этого момента школа так и не получила собственного помещения. Дарование братству собственного дома для размещения школы облегчало тем самым возможность контроля за поведением учащихся и их подготовкой к занятиям.

После такого щедрого подарка от епископа Вятского и Слободского и всего высшего духовенства в целом, на будущее братство возлагались большие надежды. 31 октября 1882 г., с разрешения Святейшего Синода, «согласно предложению Его Высокопреосвященства, Высокопреосвященнейшего Апол- 
лоса, Архиепископа Вятского и Слободского, состоялось открытие Братства Святителя и Чудотворца Николая в г. Вятке» [13, с. 563]. Братство было создано «с целью содействия епархиальным властям в их противораскольнической деятельности» [3, с. 3]. Духовенство Вятской губернии всячески высказывало свои надежды, возложенные на образованное братство. С этого момента началась деятельность Вятского братства, которое просуществовало вплоть до 1917 г. Нужно заметить, что со временем братство доказало свою состоятельность и значительно расширило сферу своей деятельности. Уставы, принятые и изменённые в 1882, 1893, 1905, 1915 гг., ярко отражали развитие деятельности братства и упрочения его позиций среди духовенства и местного правительства, а также среди населения Вятской губернии.

По инициативе Стефана Кашменского братство сконцентрировало своё внимание на миссионерской и просветительской деятельности, которую развивало через организацию школ. По образцу вятской школы в разных местностях Вятской епархии в дальнейшем при содействии Кашменского было открыто 32 школы, состоявшие также в ведении Вятского братства. Как уже отмечалось ранее, в 1886 г. благодаря активной деятельности Кашменского Вятское братство Святителя и Чудотворца Николая было принято под покровительство великого князя Сергея Александровича. В целом, деятельность отца Стефана Кашменского была направлена на религиозное просвещение населения Вятской епархии и укрепление позиций РПЦ.

Особое внимание Стефан Кашменский уделял отбору и подготовке будущих миссионеров, причём подходил к этому вопросу очень серьёзно и продуманно, что впоследствии было оценено Святейшим Синодом. Так, в § 2 Устава 1882 г. была чётко сформулирована цель создаваемого братства, которая требовала распространять «между крестьянами Вятской губернии извлечённые из старинных книг сведения об обрядах и догматах православной веры, нужные для мирных бесед с "старообрядцами", отпадшими от святой церкви» [17, с. 569]. Кашменский полагал, что «средством для осуществления» этой цели будет «подготовление взрослых крестьян из заражённых расколом приходов в Вятской школе Братства для мирных миссионерских собеседований с именуемыми старообрядцами и для первоначального обучения грамоте крестьянских детей» [3, с. 3]. Он считал, что отошедшие от ортодоксальной церкви будут скорее прислушиваться к доводам своих родственников, соседей и земляков, с которыми живут и работают бок о бок всю жизнь, а не выслушивать проповеди священников. Такие крестьяне стали бы помощниками приходских священников в проведении религиозно-просветительской деятельности среди местного населения. Кроме того, Кашменский понимал, что даже у самых ревностных приходских священников не будет возможности для ведения обстоятельных и продолжительных бесед со всеми старообрядцами и православными его прихода. В то же время специально обученный и подготовленный к таким беседам крестьянин под присмотром местных священников имел возможность для такой работы в своём родном селе или деревне. С этой позиции Кашменский подходил к воплощению своей идеи создания организации для работы со старообрядцами в жизнь.

Также нужно отметить, что опыт Стефана Кашменского в плане подготовки крестьян для работы со старообрядческим и сектантским населением в сложных в религиозном плане приходах стал распространяться при поддержке Святейшего Синода на территории всей Российской империи. Так, в определении Святейшего Синода за № 1116 от 25 мая 1888 г. были прописаны основные руководящие моменты работы со старообрядцами и сектантами, в т. ч. давались указания об «устройстве школ для подготовления способных крестьян к миссионерской деятельности среди раскольников и сектантов, по образу школы, основанной в г. Вятке протоиереем Кашменским» [3, с. 2]. Так Вятская противораскольническая школа стала образцом для создания подобных школ в Российской империи, и заслуга Стефана Кашменского была признана на общероссийском уровне. Практика обучения и подготовки для ведения миссионерской работы в первую очередь крестьянского населения была введена на государственном уровне.

После смерти Стефана Кашменского Вятское братство продолжило свое развитие. Далеко идущие планы протоиерея отразились в Уставе братства от 1882 г., в § 27 которого говорилось о том, что Совет братства также должен содействовать открытию «в г. Вятке женского отделения братской школы, руководствуясь правилами, изложенными в Уставе Братства» [17, с. 574]. Открытие женского отделения затянулось почти на десятилетие, и только после смерти Кашменского, в 1891 г. преосвященным Сергием оно было открыто. С каждым годом своей деятельности братство постепенно приближалось к осуществлению плана Стефана Кашменского. Безусловно, забота о развитии школьной деятельности была ключевым моментом в работе братства. 
Стефан Кашменский и его религиозно-просветительская и миссионерская деятельность... 599 СЕРИЯ ИСТОРИЯ И ФИЛОЛОГИЯ

С течением времени круг деятельности Вятского братства Святителя и Чудотворца Николая значительно расширился, наладились связи с другими религиозно-просветительскими организациями в Вятской губернии. К началу XX в. деятельность Вятского братства затрагивала практически все направления религиозной жизни - противостарообрядческое, иноверческое и противосектантское, а члены братства пользовались уважением и среди высшего духовенства, и среди простого населения Вятской губернии. По решению съезда, Вятское братство «в целях большей определённости и прочности его положения и жизненности деятельности его, а также в соответствии новым назревшим потребностям местной епархиальной церковно-общественной жизни... преобразовано в 1915 г. в учреждение Епархиальное, под названием "Вятское Епархиальное Братство во имя Святителя и Чудотворца Николая”, и состоит при Вятском кафедральном соборе» [18, ф. 270, оп. 1, д. 185, л. 1].

Так, ещё один пункт в программе преобразования и усиления позиций братства и расширения сферы его деятельности был выполнен, правда, уже без учредителя и главного инициатора всех преобразования - Стефана Кашменского.

Кроме всего прочего, члены братства, главным образом Стефан Кашменский, ратовали за мирные пути укрепления православной веры, поэтому в ведение братства также включалось распространение между прихожанами Вятской епархии бесплатных «самых кратких сочинений, полезных для мирных бесед со “старообрядцами”, отпадшими от святой церкви» [17, с. 569]. Тем самым подчёркивался просветительский момент в деятельности братства. Распространение брошюр и листков постепенно приобрело масштабный характер, став важной строкой расходов братства по изданию подобной печатной продукции.

Благодаря активной деятельности Стефана Кашменского члены братства Святителя и Чудотворца Николая сумели найти поддержку среди населения Вятской губернии (в границах совпадавшей с Вятской епархией) и плодотворно вели работу на всём протяжении существования братства.

Так Стефан Кашменский сыграл важную роль в организации и развитии религиозной деятельности в Вятской епархии. Выбрав новаторский путь подготовки миссионеров и уделив пристальное внимание созданию школьной сети и для взрослых, и - в главных - для детей из семей староверов, иноверцев и даже сектантов, Стефан Кашменский сумел усилить позиции РПЦ среди населения Вятской губернии, наладить плодотворную работу среди старообрядческого и неправославного населения. Опыт Стефана Кашменского по организации школ для подготовки миссионеров был взят на вооружение Святейшим Синодом как эффективный и продуктивный.

Созданное по инициативе протоиерея Стефана Кашменского и непосредственном содействии епископа в 1882 г. Вятское братство Святителя и Чудотворца Николая со временем превратилось в епархиальную организацию, которая вела работу по ключевым религиозным направлениям, важным для Вятской епархии. Благодаря заложенной Кашменским основе в конце XIX — начале XX вв. Вятское братство Святителя и Чудотворца Николая стало ведущей религиозно-просветительской и миссионерской организацией в Вятской губернии, ведавшей или содействовавшей религиозным структурам Вятской епархии. Братство Святителя и Чудотворца Николая было примером влиятельной местной религиозно-просветительской организации. Помимо братства в Вятской губернии по инициативе Стефана Кашменского был открыт Вятский комитет Православного миссионерского общества, с течением времени оказавшийся в подчинении Вятского братства.

Стефан Никифорович Кашменский прожил долгую и насыщенную жизнь. Своей деятельностью он стремился помочь укреплению позиций Русской православной церкви в Вятской губернии. После его ухода духовенство Вятской епархии продолжило работу Кашменского по укреплению позиций Вятского братства Святителя и Чудотворца Николая, по усилению влияния на старообрядческое, иноверческое и - впоследствии - сектантское население Вятской губернии. Школьная деятельность стала ключевым направлением работы Вятского братства по усилению влияния ортодоксальной церкви. Так деятельность Стефана Кашменского стала толчком к активизации религиозной работы в Вятской епархии.

\section{СПИСОК ИСТОЧНИКОВ И ЛИТЕРАТУРЫ}

1. Братство в г. Вятке // Вятские епархиальные ведомости. 1882. № 19. Отдел духовно-литературный. С. $515-516$.

2. Вятка, 28 янв. // Вятские епархиальные ведомости. 1889. № 3. С. 47-48.

3. Вятское Братство Святителя и Чудотворца Николая в 1906-7 отчётном году. Вятка, 1908. 112 с. 
4. Двадцать пять лет Вятского Братства Святителя и Чудотворца Николая (31 октября 1882 года - 31 октября 1907 года). Исторический очерк // Вятские епархиальные ведомости. 1908. № 11. Отдел неофициальный. С. $291-310$

5. Кашменский С. Краткое руководство к собеседованию с мнимыми старообрядцами, отпадшими от святой церкви: С изображением именословно благословляющего Спасителя, заимствованным из книги Триодион, напечатанной за двадцать пять лет до патриаршества Никона. Вятка, 1878. 58 с.

6. Кашменский С. Систематический свод учения святых отцов церкви о душе человеческой. Ч. 1. Вятка. 1860. $199 \mathrm{c}$.

7. Кашменский С. Систематический свод учения святых отцов церкви о душе человеческой. Ч. 2. Отдел 1-3. Вятка, 1865. 297 с.

8. Кашменский С. Систематический свод святоотеческих изречений, служащих к изъяснению божественной литургии, составленный вятским кафедральным протоиереем Стефаном Кашменским. Вятка, 1878. 79 с.

9. Костров Иоанн. Слово при погребении Кафедрального отца протоирея Стефана Никифоровича Кашменского 31 января 1889 года // Вятские епархиальные ведомости. 1889. № 4. Отдел духовно-литературный. С. 95-100.

10. Машковцев А. А. Миссионерская деятельность протоиерея Стефана Кашменского среди сарапульских молокан // Церковь в истории и культуре России: сб. материалов междунар. науч. конф., посвящ. памяти преподобного Трифона Вятского (1546-1612), г. Киров, 22-23 окт. 2010 г. Киров, 2010. С. 347-350.

11. Машковцева В. В. Миссионерская деятельность Вятского братства Святителя и Чудотворца Николая среди старообрядцев // Вестн. Вят. гос. гуманитар. ун-та. 2003. № 8. С. 145-150.

12. Миссионерская деятельность в Вятской епархии в 1875 году // Вятские епархиальные ведомости. 1876. № 10. Отдел духовно-литературный. С. 269-278.

13. Открытие Вятского Братства Святителя и Чудотворца Николая // Вятские епархиальные ведомости. 1882. № 22. Отдел духовно-литературный. С. 563-568.

14. Плетенёв К. В. Миссионерско-просветительская деятельность Вятского братства во имя свт. и чудотворца Николая в кон. XIX - нач. XX в. // Религия и Церковь в культурно-историческом развитии Русского Севера: материалы междунар. науч. конф. Киров, 1996. Т. 1. С. 280-283.

15. Ратьков-Рожнов В. Протоиерей Вятского кафедрального собора Стефан Никифорович Кашменский // Календарь и памятная книжка Вятской губернии на 1894 г. Вятка, 1893. С. 435-448.

16. Речь на отпевании Кафедрального Протоиерея Стефана Никифоровича Кашменского // Вятские епархиальные ведомости. 1889. № 4. Отдел духовно-литературный. С. 100-104.

17. Устав Вятского Братства Святителя и Чудотворца Николая // Вятские епархиальные ведомости. 1882 . № 22. Отдел духовно-литературный. С. 568-576.

18. Центральный государственный архив Кировской области (ЦГА КО). Ф. 270. Оп. 1. Д. 185. Совет Вятского Братства Святителя и Чудотворца Николая. Устав Вятского Епархиального Братства.

19. Царёва E. В. К вопросу о деятельности Вятского братства свт. и чудотворца Николая (1882-1916 гг.) // Религия и Церковь в культурно-историческом развитии Русского Севера: материалы междунар. науч. конф. Киров, 1996. Т. 1. С. 277-280.

Поступила в редакцию 22.05.2019

Половникова Марина Юрьевна, кандидат исторических наук, доцент кафедры истории

и политических наук

ФГБОУ ВО «Вятский государственный университет»

610000, Россия, Кировская область, г. Киров, ул. Московская, 36

E-mail:pmina@mail.ru

\section{M.Yu. Polovnikova \\ STEFAN KASHMENSKY AND HIS RELIGIOUS-EDUCATIONAL AND MISSIONARY ACTIVITIES IN THE VYATKA PROVINCE IN THE SECOND HALF OF THE XIX CENTURY}

DOI: $10.35634 / 2412-9534-2019-29-4-593-602$

The article examines the life and work of one of the prominent missionaries and enlighteners of the Russian Empire of the second half of the 19th century, Stefan Kashmensky, based on archival materials and published sources. By virtue of the changed religious policy in the Russian Empire in the second half of the nineteenth century there were changes in religious education and missionary work in the Vyatka province. In the Vyatka Diocese, a special contribution to the development of missionary activity was made by the diocesan missionary, the archpriest Stefan Kashmensky. The article reflects the contribution of Stefan Kashmensky to the organization of full-fledged work with the Gentiles and Old Believers. To strengthen the work with non-believers on his initiative, the Vyatka Committee of the Orthodox Mission- 
Стефан Кашменский и его религиозно-просветительская и миссионерская деятельность... 601 СЕРИЯ ИСТОРИЯ И ФИЛОЛОГИЯ

ary Society was opened in the Vyatka province. Stefan Kashmensky contributed to the reorganization of missionary work with the Old Believers in the Vyatka Diocese. To this end, he, with the support of the clergy, opened an antischolastic school in the city of Vyatka to train missionaries from among the peasants. According to the decree of the Holy Synod, the experience of organizing schools against old believers was to spread throughout the Russian Empire. But the main result of the work of Stefan Kashmensky was the creation of the Vyatka brotherhood of St. Nicholas, which led the work in three main areas: with the Old Believers, with the non-Russian population and, later, with the sectarians. Thus, Stefan Kashmensky, through his activity, managed to improve the position of the Russian Orthodox Church in the Vyatka province and prepare missionaries for conducting religious work in all religious areas in the Vyatka Diocese.

Keywords: Russian Orthodox Church, Vyatka province, Vyatka eparchy, Stefan Kashmensky, missionary work, old belief.

\section{REFERENCES}

1. Bratstvo $\mathrm{v}$ g. Vyatke [Brotherhood in Vyatka town]. Vyatskie eparhialnyie vedomosti [The Vyatka diocesan statements], 1882, no. 19, pp. 515-516. (In Russian).

2. Vyatka, 28 yanvarya [Vyatka, 28 of January]. Vyatskie eparhialnyie vedomosti [The Vyatka diocesan statements], 1889, no. 3, pp. 47-48. (In Russian).

3. Vyatskoe Bratstvo Svyatitelya i Chudotvortsa Nikolaya v 1906-7 otchetnom godu [The Vyatka's Brotherhood of St. Nikolas in 1906-1907 reporting years]. Vyatka, 1908. (In Russian).

4. Dvadtsat pyat let Vyatskogo Bratstva Svyatitelya i Chudotvortsa Nikolaya (31 oktyabrya 1882 goda -31 oktyabrya 1907 goda). Istoricheskiy ocherk [Twenty five years of Vyatka's Brotherhood of St. Nikolas (1882, 31 October 1907, 31 October). A historical feature article]. Vyatskie eparhialnyie vedomosti [The Vyatka diocesan statements], 1908, no. 11, pp. 291-310. (In Russian).

5. Kashmenskiy $S$. Kratkoe rukovodstvo k sobesedovaniyu s mnimyimi staroobryadtsami, otpadshimi ot svyatoy tserkvi: S izobrazheniem imenoslovno blagoslovlyayuschego Spasitelya, zaimstvovannyim iz knigi Triodion, napechatannoy za dvadtsat pyat let do patriarshestva Nikona [A quick guide to interviewing imaginary Old Believers who fell away from the holy church: With an image of the literary blessing Savior, borrowed from the book Triodion, printed twenty-five years before the patriarchate of Nikon]. Vyatka, 1878. (In Russian).

6. Kashmenskiy S. Sistematicheskiy svod ucheniya svyatyih ottsov tserkvi o dushe chelovecheskoy: Part 1 [A systematic set of teachings of the holy fathers of the church about the human soul]. Vyatka, 1860. (In Russian).

7. Kashmenskiy S. Sistematicheskiy svod ucheniya svyatyih ottsov tserkvi o dushe chelovecheskoy: Part 2 [A systematic set of teachings of the holy fathers of the church about the human soul]. Vyatka, 1865. (In Russian).

8. Kashmenskiy S. Sistematicheskiy svod svyatootecheskih izrecheniy. Sluzhaschih k iz'yasneniyu bozhestvennoy liturgii, sostavlennyiy vyatskim kafedralnyim protoiereem Stefanom Kashmenskim [A systematic collection of patristic sayings serving to the explanation of the divine liturgy, compiled by the Vyatka cathedral archpriest Stephen of Cashmen]. Vyatka, 1878. (In Russian).

9. Kostrov Ioann. Slovo pri pogrebenii Kafedralnogo ottsa protoireya Stefana Nikiforovicha Kashmenskogo 31 yanvarya 1889 goda [The speech at the burial of the Cathedral father of archpriest Stefan Nikiforovich Kashmensky on January 31, 1889]. Vyatskie eparhialnyie vedomosti [The Vyatka diocesan statements], 1889, no. 4, pp. 95-100. (In Russian).

10. Mashkovtsev A. A. Missionerskaya deyatelnost protoiereya Stefana Kashmenskogo sredi sarapulskih molokan, Tserkov v istorii i kulture Rossii [A missionary activity of archpriest Stefan Kashmensky among Sarapol Molokans]. Sbornik materialov Mezhdunarodnoy nauchnoy konferentsii, posvyaschennoy pamyati prepodobnogo Trifona Vyatskogo (1546-1612), g. Kirov, 22-23 oktyabrya 2010 goda [Church in the history and culture of Russia. Collection of materials of the International Scientific Conference dedicated to the memory of St. Trifon Vyatsky (1546-1612), Kirov, October 22-23, 2010]. Kirov, 2010, pp. 347-350. (In Russian).

11. Mashkovceva V. V. Missionerskaya deyatelnost Vyatskogo bratstva Svyatitelya i Chudotvorca Nikolaya sredi staroobryadcev [The missionary activity of the Vyatka brotherhood of St. Nicholas among Old Believers]. Vestnik Vyatskogo gosudarstvennogo gumanitarnogo universiteta [Vestnik of the Vyatka State Humanitarian University], 2003, no. 8, pp. 145-150. (In Russian).

12. Missionerskaya deyatelnost v Vyatskoy eparhii v 1875 godu [A missionary's activity in 1875]. Vyatskie eparhialnyie vedomosti [The Vyatka diocesan statements], 1876, no. 10, pp. 269-278. (In Russian).

13. Otkryitie Vyatskogo Bratstva Svyatitelya i Chudotvortsa Nikolaya [The opening of the Vyatka's Brotherhood of St. Nikolas]. Vyatskie eparhialnyie vedomosti [The Vyatka diocesan statements], 1882, no. 22, pp. 563-568. (In Russian).

14. Pletenev $K$. $V$. Missionersko-prosvetitelskaya deyatelnost Vyatskogo bratstva vo imya svt. i chudotvorca Nikolaya $\mathrm{v}$ kon. XIX - nach. XX v. [Missionary and educational activities of the Vyatka Brotherhood of St. Nicholas in the con. XIX - beg. XX century]. Religiya i Cerkov v kulturno-istoricheskom razvitii Russkogo Severa: Materialy 
Mezhdunarodnoy nauchnoy konferentsii [Religion and the Church in the cultural and historical development of the Russian North: Proceedings of the Intern. scientific conf.]. Kirov, 1996, v. 1, pp. 280-283. (In Russian).

15. Ratkov-Rozhnov V. Protoierey Vyatskogo kafedralnogo sobora Stefan Nikiforovich Kashmenskiy [Archpriest of the Vyatka Cathedral Stephan Nikiforovich Kasmensky]. Kalendar i pamyatnaya knizhka Vyatskoy gubernii na $1894 \mathrm{~g}$. [Calendar and a memorial book of the Vyatka province in 1894]. Vyatka, 1893, pp. 435-448. (In Russian).

16. Rech na otpevanii Kafedralnogo Protoiereya Stefana Nikiforovicha Kashmenskogo [The speech at the funeral of Cathedral Archpriest Stefan Nikiforovich Kashmensky]. Vyatskie eparhialnyie vedomosti [The Vyatka diocesan statements], 1889, no. 4, pp. 100-104. (In Russian).

17. Ustav Vyatskogo Bratstva Svyatitelya i Chudotvortsa Nikolaya [The statute of the Vyatka's Brotherhood of St. Nikolas]. Vyatskie eparhialnyie vedomosti [The Vyatka diocesan statements], 1882, no. 22, pp. 568-576. (In Russian).

18. Centralnyj gosudarstvennyj arhiv Kirovskoj oblasti (CGA KO) [The Central State Archive of the Kirov region]. F. 270. Op. 1. D. 185. Sovet Vyatskogo Bratstva Svyatitelya i Chudotvorca Nikolaya. Ustav Vyatskogo Eparhialnogo Bratstva [The Council of the Vyatka Brotherhood of St. Nicholas. Charter of the Vyatka Diocesan Brotherhood]. (In Russian, inpublished).

19. Tcareva E. V. K voprosu o deyatelnosti Vyatskogo bratstva svt. i chudotvorca Nikolaya (1882-1916 gg.) [To the Question of the Activity of the Vyatka Brotherhood of St. Nicholas (1882-1916)]. Religiya i Cerkov v kulturnoistoricheskom razvitii Russkogo Severa: Materialy Mezhdunar. nauch. konf. [Religion and the Church in the cultural and historical development of the Russian North: Proceedings of the Intern. scientific conf]. Kirov, 1996, v. 1, pp. 277-280. (In Russian).

Received 22.05.2019

Polovnikova M.Yu., Candidate of History, Associate Professor at Department of History and Political Sciences Vyatka State University

Moskovskaya st., 36, Kirov, Russia, 610000

E-mail:pmina@mail.ru 